\title{
Re-Narrating the Postcolonial Subject within Neo-Liberal Spaces: A Study on the Role of Travel as Depicted in the Contemporary Postcolonial Novel
}

\author{
Isuru Ayeshmantha Rathnayake \\ Lecturer in the Department of English, the University of Kelaniya, Sri Lanka. \\ Mail Id: isuruay_2019@kln.ac.lk
}

\begin{abstract}
The objective of this study is to re-interpret the idea of travel, represented in the postcolonial novel, as a motif that brings out the dialectic influence of neo-liberal values in defining the contemporary postcolonial subject. As a literary cannon, postcolonial literature is primarily concerned with bringing into light the experience of being colonised by the "white" Europeans, and the struggles of oscillating between two value systems, i.e., the indigenous value systems and the values brought into the colonies by the colonisers. Therefore, the years after 1950s saw the emergence of a host of authors, who in their mother tongue or in the coloniser's tongue narrated such experiences, while various Eastern and Western critics were interested in theorising the postcolonial subject. The present study contends that, a break in the continuity of such a tradition could be observed with the global spread of neo-liberalism during late 1970s and 1980s, which could be discerned through how the idea of travel being represented in the postcolonial novel. Through a close reading of Amitav Ghosh's In an Antique Land (1992) and Aravind Adiga's The White Tiger (2008), the study points out the significant role the idea of travel can play in portraying the neo-liberal dialect which has restructured the traditional relationship between colonised and the coloniser. It argues that the emergence of multiple centres of power, liquidation of geographical boarders and the rapid economisation of all spheres of life, have made the polarised relationship of a colonised and a coloniser redundant, demanding a re-narration of postcolonial subjectivity.
\end{abstract}

Keywords: Postcolonial Literature, Travel, Neo-Liberalism

\section{Introduction}

The discovery of sea roots that enabled the Europeans to travel to the eastern parts of the world marked a significant juncture in the world history, that changed the trajectory of global affairs. Thus began an era of colonial domination where the newfound colonies were seen as "posts for trade and strategic settlement" (Macleod, 1). Within this context, "colonies served as plantations or primary producers for the trade or manufacturing industries of the metropolis", creating in that process a power hierarchy that subjugated the natives (Macleod, 1). On the other hand, was the 
devaluation of the indigenous knowledge systems, which Sefa defines as the rejection of "ideas and cultural knowledges of local peoples concerning the everyday realities of living" (ㅁ). A direct outcome of such endeavors was to establish western knowledge/values in a position of power, effectively constructing a binary relationship that subjugated the native. For instance, rule of the king/queen was regarded as less democratic in the face of constitutional governance, while incantations and exorcisms for treating the sick were dismissed in favour of western medical science. As critics such as Sefa points out, the colonised managed to achieve the so-called modernisation as a result of such drastic changes to their traditional life patterns, and maybe at the cost of what was dear and familiar to them.

When the years of colonial domination was drawn to an end around the mid-twentieth century, the socio-economic and the political fabric of the colonies was irrevocably changed, and the natives were plunged into a new reality which was foreign to them. Suddenly, there were two dominant knowledge systems for the natives to choose from, which they have inherited through their ancestral lineage and the colonial legacy. In the meantime, countries such as Sri Lanka and India were struggling with the irruption of ethnic unrests that were brewing during the colonial era. Postcolonial individual/subject was the outcome of all these intersecting forces which situated the post-independent "man" in a position of contestation and ambiguity.

As argued by Ashcroft, Griffiths and Tiffin in The Empire Writes Back (referred hereafter as TEWB), the term postcolonial thus emerged "to cover all the culture affected by the imperial process from the moment of colonization to the present" $(\underline{1})$. They further argue,

"So the literatures of African countries, Australia, Bangladesh, Canada, Caribbean countries, India, Malaysia, Malta, New Zealand, Pakistan, Singapore, South Pacific Island countries, and Sri Lanka are all post-colonial literatures" (TEWB2).

What is witnessed here is the emergence of a new literary tradition, one that is characterised by the unique experiences of the eastern parts of the world which for centuries have been under the domination of the western world. It also ruptured the representation of the East by the West by reclaiming the right to portray the East by the East, which in turn added a new layer of experiences to the already rich fabric of world literature. As asserted by Ashcroft, Griffiths, and Tiffin ( TEWB 1)

"And it is in their writing, and through other arts such as painting, sculpture, music, and dance that the day-to-day realities experienced by colonized peoples have been most powerfully encoded and so profoundly influential".

Thus, it gave birth to an era of new literature which portrayed in words, colours and moving pictures what it means to own the hyphenated identity, post-colonial subject. "Writers as diverse as Chinua Achebe and Wole Soyinka from Nigeria, Salman Rushdie and Arundhati Roy from India, Derek Walcott from the Caribbean, Seamus Heaney from Ireland, Margaret Atwood and Michael Ondaatje from Canada, Peter Carey and Patrick White from Australia, and J. M. Coetzee and Nadine Gordimer from South Africa have been prominent, when portraying "the experiences of the postcolonial subject, "and their works now appear on numerous school and university syllabuses" 
(Innes, 1). Their work also has been translated into several languages while garnering attention in the East and the West alike.

A close examination of the early postcolonial literature highlights the fact that they share salient characteristics which in turn reflect the key struggles faced by the post-independent nations. As pointed out by Ashcroft, Griffiths, and Tiffin (TEWB 2)

"What each of these literatures has in common beyond their special and distinctive regional characteristics is that they emerged in their present form out of the experience of colonization and asserted themselves by foregrounding the tension with the imperial power, and by emphasizing their differences from the assumptions of the imperial centre. It is this which makes them distinctively post-colonial".

Therefore, postcolonial writing essentially became a response to the supremacy of the white colonialism, and their representations of the colonial other. These writers embarked on a journey of writing back from the peripheries to the centre, which they interpreted as an overturning of the colonial power hierarchy where the centre was vested with the power to write to the peripheries. Within this process of writing back to the centre, controversial issues of nation building, legacy of the native speakers who could speak English and "the degree to which the colonized people are able to resist, adapt to or subvert" the residual colonial powers are contested (Innes, 2). These forces constituted what is popularly known as the postcolonial subject, who derives its legitimacy through the binary relationship between the East and the West.

This polarised relationship between the colonised and the coloniser was thrown into question with the advent of neo-liberal economic policies. Late 1970s and early 1980s saw a rapid change in the national economic policies of the countries all around the world, where the governments started to re-evaluate their policies of state welfarism in a move to restructure themselves as more market dependent (Reinhoudt and Audier, 11). This led to a departure from the economic policies that demanded the government to be epicenter of a country's economic life, a role that is increasingly replaced by the private enterprises, multinational organisations, and entrepreneurs. Therefore, Neoliberalism can be understood as a resurgence of the 19th-century ideas associated with laissez-faire economic liberalism which became a reactionary movement against Keynesian economics. The countries across the world were quick to embrace this new economic policy because, most of them were struggling to steer themselves under the heavy burden of having to be the frontliner of crumbling economies due to corruption, unplanned economic policies, and the constant reliance of the public upon the state.

Taking this departure from welfarist state policies to adopt a more neo-liberal worldview as its starting point, this research argues that it has led to a reconfiguration of the postcolonial subject. For instance, one of the key outcomes of the neo-liberal economic policies was the emergence of a multiplicity of centres who can influence the global politics to a large extent. Countries such as China and South Korea have established themselves as key players not only in the politics of East Asia but also in the global arena, whereas India has made its presence felt both in the Indian subcontinent and in almost all of the other countries. A case in point that substantiates this 
argument is the nuclear energy, now used by over 50 countries across the world to meet their daily energy requirements (Nuclear Association). As pointed out by the Nuclear Association,

"Today the nuclear industry is characterised by international commerce. A reactor under construction in Asia today may have components supplied from South Korea, Canada, Japan, France, Germany, Russia, and other countries. Similarly, uranium from Australia or Namibia may end up in a reactor in the UAE, having been converted in France, enriched in the Netherlands, deconverted in the UK and fabricated in South Korea".

The above statement is a classic example to understand the changing direction of the global economic currents where it is no longer focused on one centre as the controller of the world economy. This change in the global dialectic is what defines our understanding of the postcolonial subject in the contemporary society. Being able to establish itself as the dominant thrust of the global economy within a short period of time and having influenced not only the economic spheres but also the socio-cultural and political affairs of the countries around the world, neo-liberal principles have had a strong influence in the way the postcolonial nations operate today. Countries such as Sri Lanka opened themselves to these neo-liberal forces around late 1970s, whereas the postcolonial nations like India and South Africa are no longer interpreted as the countries of the margins. Such a reconfiguration of the world affairs due to neo-liberal forces challenged the reading of postcolonial experiences only as a result of the centre-periphery relationship, where the white colonisers and the natives are always described in terms of an inequal balance of power. In light of that, this study close reads the two selected novels, In an Antique Land by Amitav Ghosh and The White Tiger by Aravind Adiga to understand how emerging postcolonial literatures have responded to such contemporary changes, which is essential to understand the evolving trajectory of the postcolonial studies. In this regard, the present study focuses on the idea of travel as represented in the selected texts and interprets it as a key motif that is capable of capturing the nuances of such changes. In the meantime, this study intends to argue for the importance of promoting inter-disciplinary and multi-disciplinary approaches when understanding the postcolonial subject, whose identity is constantly reworked by the intersecting economic, social, cultural, and political forces which it comes to contact with.

\section{Methodology}

This study uses close-reading and critical analysis as its primary research methods to understand the selected texts as responses to the contemporary socio-political and economic developments in the postcolonial nations. Published in 1992,In an Antique Land by Amitav Ghosh brings together two narratives that straddle two different eras of history. In its historical narrative that runs parallel to the semi-autobiographical account of Ghosh's life in Lataiffa, he reconstructs the history of a twelfth century Jewish merchant, Abraham Ben Yiju, and his slaves Ashu and Bomma (Ghosh, 1). Using these parallel plot lines, Ghosh engages with portraying a "history of humanity with discursive discourses" which is crucial to understand the changing landscape of the postindependent nations ( $\underline{\text { Venkateswarlu }}, 3)$. Through an anthropological reading of the pre-colonial 
and postcolonial histories, Ghosh lays the ground for an important discussion of travel as a recurrent force that has pushed people to traverse different terrains. Such experiences resulted in an in-flux of identities which in turn may help to break away from strict definitions of an individual's subjectivity.

The novel, The White Tiger by Aravind Adiga narrates the story of Balram Halwai, who moves from being a "half-baked" Indian village boy to a self-taught entrepreneur (Adiga, 8). During his journey of re-imagining his identity as an individual, Balram travels to different parts of India, from Laxmangarh to Dhanbad to New Delhi, the influence of which is evident in the way his character develops. Thus, by using a hackneyed narrative trope of rag to riches Adiga invites his readers to witness how Balram's character is defined by the agency he gains by travelling from one place to the other.

In its analysis of the above novels, this study re-interprets the postcolonial concepts such as centre-periphery relationship, postcolonial ambivalence, and the hybrid individual by approaching them through a neo-liberal perspective. For instance, it throws into question the centre-periphery relationship between the white coloniser and the colonised, by contending that there is no longer a single centre which dominates the rest of the world. This helps to re-interpret the attachment of the postcolonial subject to its traditional centre, which is conventionally described through a strict binary relationship. Similar to this was the hybridity resulted by the demand to choose from two knowledge systems, one that relates to the ancestral history of the colonised, and the other that has been imposed upon them by the colonisers. Globalisation, which as a concept thrives on the increased networks between people across countries, exposed the individual to the practices and knowledges of different parts of the world, thereby debunking the postcolonial understanding of the concept of hybridity. This study argues that such changes in the postcolonial landscape are reflected in the literature produced in post-independent nations through the idea of travel. As asserted by (Buzard 37),

"All knowledge is produced from the impressions' drawn in through the five senses. If knowledge is rooted in experience and nowhere else, travel instantly gains in importance and desirability" (Festino, 327).

Viewed in this light, the experience of travel becomes a way of traversing unknown lands and gathering new experiences, which work to widen the horizon of an individual's understanding of his or her own subjectivity. Applied to the context of the above discussion, the motif of travel therefore helps to re-interpret the postcolonial subject in the ever-changing landscapes of postindependent nations. It also accords renewed significance to the interpretation of travel narrative as a genre that brings "historically, geographically and culturally apart people" to one contact zone (Festino, 326). 


\section{Re-configuring the Postcolonial Subject within Neo-liberal Spaces}

"The future of the world lies with the yellow man and the brown man, now that our erstwhile master, the white-skinned man, has wasted himself through buggery, cell phone usage, and drug abuse...." (Adiga, 4).

Although tinged with a hint of sarcasm, the above extract is apt at shedding light onto the changing dialectic of the global political arena. As discussed above, the popularization of the neo-liberal economic policies saw the rising of various countries such as India and China into positions of power in the global politics. As Balram, Adiga's protagonist in the novel The White Tiger points out, some of those countries have surpassed the traditional epicenters of power such as the United Kingdom, thereby giving rise to a host of new relationships among the newly emerged world powers. Therefore, Adiga's opening remark that the prime minister of China is visiting India "in a mission to know the truth about Bangalore" demands attention, as it directs our attention to the relationships that have sprung between such emerging powers (Adiga, 3. Unlike in a traditional postcolonial dialect which is concerned with the flow of knowledge from the West to the East, and the attempts of the East to overturn this power relationship, it is possible to observe mutual learning between a multiplicity of centres, examples for which would be the exchange programmes for students, visits of foreign delegates and cultural exhibitions. Therefore, the visit of the Chinese prime minister justifies the changing political priorities of the postcolonial nations which in turn impacts the definition of the postcolonial subject.

What is brought into light with this emergence of a multiplicity of centres, is the blurring of otherwise static boundaries both in its geographical and metaphorical sense (Mooney and Evans). As further explained by Mooney and Evans, "people as individuals are circulating in an increasingly de-territorialising world", which is a direct outcome of the neo-liberal economic practices (106). Neo-liberalism as an economic philosophy thrives on the constant flow of human, finance, and other resources across geographical boundaries to facilitate the economic needs of multinational businesses. Within this new reality, individuals are interpreted as global fluids who belong to an increasingly de-territorialising world where they can flow in any direction that they desire without any constraints (Mooney and Evans). Thus, Ghosh as a postcolonial anthropologist who was born in India and educated in the United Kingdom can travel to Egypt, where he is received as an "insider" as well as an "outsider" by the villagers (Leeds, 2). For the villagers he is an insider because he belongs to a post-independent nation that is ravished by the imperialistic project, while his very allegiance to the European centres through his education makes him an outsider (Ghosh, 235). What is important here for us is the fact that he can traverse these spaces easily and locate himself, while swiftly moving from one identity to the other. Therefore, what is evident to us is an in-flux of identities from which one can choose, a phenomenon which may challenge the fossilised relationship between a coloniser and the colonised. The significance accorded by the neoliberal principles to the individual self also contributes to this reading, as it justifies the individual's power to decide who he or she is. 
A close observation of Balram's character is important to nuance this reading of individual self within the contemporary postcolonial landscape. In Laxmangarh, Balram was only known as "Munna", "boy" in English, and worked at a tea shop (Adiga, 17). After his father's death, Balram came to the city of Dhanbad where he gained the opportunity to become a driver (Adiga, 28). His subsequent life in New Delhi and Bangalore saw him becoming an entrepreneur, a proud owner of a transport service. What is evident through the above description is a shift in identity which is resulted by the shifting geographical spaces. In his village the opportunities he had were limited, whereas in Bangalore Balram was flooded with the possible means of investing the money he stole from his late master Mr. Ashok (Adiga, 178). This example captures the significant role travel plays in defining the contemporary postcolonial individual. As Balram once points out,

"Please understand, Your Excellency, that India is two countries in one: an India of Light, and an India of Darkness. The ocean brings light to my country. Every place on the map of India near the ocean is well off. But the river brings darkness to India - the black river. Which black river am I talking of... I am talking of Mother Ganga" (Adiga, 10)

The above statement throws into relief how the places we inhabit are intrinsically politicised, and therefore have the power to both liberate and suffocate its inhabitance. Within such a reading, the capacity to travel from one place to the other acquires more significance, allowing us to interpret such an ability as an agent of empowerment.

It is also important to note that, the idea of travel is not always associated with the physical act of travelling as portrayed in the selected texts. For instance, Ghosh refers to his transistor radio which bridges him with the outside world, while a television set acquired by one of the villagers, a school master, became the main source of entertainment for the youth in the village (Ghosh, 20-21). Although such examples refer to the initial stages of global media reaching the far corners of the world, they are crucial in mapping the transformation of the postcolonial subject (Venkateswarlu, p.2). The same could be observed in the narrative of the slave merchant where the primary means of communication was through the exchange of letters. What is evident here is Ghosh's fascination with narrating postcolonial subjects as "global citizens" "in today's transnational world" (Kalpakli, 4). A similar view can be expressed about Balram in The White Tiger, who observes his "silver Macintosh" computer as his main link to the outside world (Adiga, 20). Furthermore, Balram boasts in the novel about his transport service which has its own website, and about his ability to track his vehicles virtually. In light of the above evidence, we witness the emergence of a new form of citizenship, which requires us to revisit the idea of the postcolonial subject to nuance it to match the undercurrents of the twenty first century. The presence of internet along with the other means of communication that have become so mundane in the contemporary society interpolate people around the world to embrace the idea of a global citizenship. Thus, the priorities of a traditional postcolonial subject might get overwritten by these new forms of citizenship, thereby leading to a reconfiguration of the postcolonial subject. However, it should be noted that, this global citizenship has its own prerequisites, Ghosh is a postcolonial anthropologist with a European education, whereas Balram the entrepreneur is a wealthy gentleman living in one of the rapidly developing cities of India. Thus, both these individuals are coming from positions of 
power where they are safe from the socio-economic forces that may work to marginalize the disadvantaged communities. Therefore, it highlights the significance of the postcolonial theory as a tool to resist the modern forms of neo-colonisation which may push the postcolonial subject further towards the periphery.

This study also aims to re-interpret the role of a hybrid individual within the contemporary postcolonial landscape. Developed to explain the experiences of the postcolonial individuals who are trapped between the indigenous and the western knowledge systems, hybridity can be defined as an "active moment of challenge and resistance against a dominant colonial power" (Ashcroft, Griffiths, and Tiffin, in Postcolonial studies the Key Concepts, referred hereafter as PSKC, 106). As Bhabha argues, the concept of hybridity allows the postcolonial individual to return to a third space, a space that is situated outside the two dominant value systems, where "the performance of identity as iteration" and "the re-creation of the self" becomes a reality (11). It deprives "the imposed imperialist culture, not only of the authority that it has for so long imposed politically, often through violence, but even of its own claims to authenticity" (Ashcroft, Griffiths and Tiffin, 106). Observed in this regard, the predominant concern of the concept of hybridity is to theorise the experiences of the post-independent individuals who occupy this alternative third space. However, the above discussion highlighted how they have been thrusted into a new reality by the neo-liberal forces that expose them constantly to a multiplicity of cultures, which in turn complicates their hybrid identity. Therefore, the subjectivity of a postcolonial individual is multilayered and multifaceted, to understand which the idea of hybridity and the forces of neo-liberalism are needed to be brought into the same table. For example, Balram, who have been exposed to various parts of India is shaped by those multiple encounters, while his former employee Mr. Ashok and his x-wife Pinky Madam spent their lives oscillating between both eastern and western cultures. The same can be said about Ghosh, who was born in India, studied in the United Kingdom, lives in Egypt in the course of the novel, while writing about a twelfth century slave merchant and his slaves. Thus, it is not the meeting of two dominant knowledge systems that we can expect in Bhabha's third space, but a multiplicity of experiences which come to define the postcolonial subject. Therefore, there is a potent necessity to extricate ourselves from this polarised way of observing the postcolonial subject, an idea that can be clearly understood by the portrayal of the concept of travel in the postcolonial novel.

Another brewing tension in the contemporary postcolonial literature is the economisation of the all spheres of life. In Ghosh's account of the rural village of Lataifa, we meet Abu-'Ali, the village merchant who owns the only one "government-subsidized shop for retailing essential commodities at controlled prices" (hosh, 22). Ghosh points out,

Often his customers were more supplicants than patrons, for there was nothing to prevent him from choosing whom to sell to: people who got on the wrong side of him frequently discovered that he was out of tea or kerosene or whatever it was they wanted. It was all the same to Abu-'Ali: he had no shortage of customers - they had to come to him or go all the way to the next village, Nashâwy, a mile and a half down the road. It was thus that Abu-'Ali had grown so large" (Ghosh, 22-23). 
Neo-liberalism as an economic policy is characterised by the efficiency with which it maximised the profit in any transaction. Thus, seeping of such values to the mundane lives of the individuals saw how their actions were slowly turned into the manifestations of consumeristic intentions. Viewed in this light, for AbuAli, the villagers were mere customers whose value, as so far as he is concerned, ends with their unwillingness to trade with him. The same is true for the character Balram who aimed to "ape his masters" in his transactions (Satin, 2). Thus, he exerts his financial strength to put the competing transport services out of business and bribe a police officer to get one of his drivers released after he crashed a cyclist while at duty. These examples are important in pointing at the issues raised by the rapid economisation of life, as a direct outcome of the laissez-faire economic policies which legitimized the financial strength as the yardstick of measuring justice. Such developments demand postcolonial studies to reposition itself to address them, re-evaluating its role within a neo-liberalised postcolonial landscape.

\section{Conclusion}

The present study engaged with the representation of travel in the postcolonial novel as a means of understanding the changing landscape of the post-independent countries. For instance, by close reading the two texts In an Antique Land and The White Tiger, the study analysed how the popularization of the neo-liberal values has changed the experiences of postcolonial subject. It contended that, there is no longer a polarised relationship between a white colonial centre and a periphery, a relationship that has been irrevocably changed by the multiple centres of power that have emerged over time. Furthermore, it expounds that the ease with which one can cross the geographical and metaphorical boundaries has led to a free flow of humans, goods, and finance across borders, giving rise to the idea of global citizenship. It also argued for the need to re-think the concept of hybridity within a neo-liberal framework, while contending for the drastic impact the rapid economisation of life may have upon the postcolonial individual. Therefore, it concludes that, there is a potent necessity to re-evaluate the concepts of postcolonial studies through a neo-liberal viewpoint which has become the dominant ideology that governs the world affairs. It also emphasises that such changes in the understanding of the postcolonial subject reaffirms the centrality of the postcolonial theories when defining ourselves to match the global dialectic.

\section{References}

Adiga, Aravind. The White tiger. United Kingdom: Atlantic Books

Ashcroft, Bill., Griffiths, Gareth. and Tiffin, Helen. The Empire Writes Back: Theory and Practice in Post-

Colonial Literatures. United Kingdom: Psychology Press, 1989.

Ashcroft, Bill., Griffiths, Gareth. and Tiffin, Helen. Postcolonial Studies: The Key Concepts. London: Routledge,

2013 
Bhabha, Homi. The Location of Culture. London : Routledge, 1994.

Festino, Cielo. Hybridity and travel writing in English: the grand tour and the imperial frontier Letras \& Letras, 2010. https:// www.researchgate.net/publication/228502261. $18^{\text {th }}$ Nov. 2021

Ghosh, Amitav. In An Antique Land. USA: Vintage, 1992.

Innes, Catherine. The Cambridge introduction to postcolonial literatures. Cambridge: Cambridge University press, 2007.

Kalpakli, Fatma. Blurring of the Borders in Amitav Ghosh's Novel, In an Antique Land The Journal of International Social Research, 2016. https://www.researchgate.net > publication > 311905073_... 15 th Nov. 2021

Leeds, Claire. Anthropology as Cultural Translation: Amitav Ghosh's In an Antique Land The Postcolonial Text. https:/ / www.researchgate.net > publication > 260386306_... 18 ${ }^{\text {th }}$ Nov. 2021

Macleod, Roy. Reading the Discourse of Colonial Science. N.d. https://horizon.documentation.ird.fr > carton07. 16 th Nov. 2021

Mooney, Annabelle. And Evans, Betsy. Globalisation: the Key Concepts. London: Routledge, 2007

Nuclear Association. Nuclear Power in the World Today. https://world-nuclear.org > current-and-futuregeneration. $18^{\text {th }}$ Nov. 2021

Reinhoudt, Jurgen. And Audier, Serge. The Walter Lippmann Colloquium; The Birth of Neo-Liberalism. New York: Springer International Publishing, 2018

Satin, Shikha. Predicaments of Self in a Globalising India: The Locus of Identity in The White Tiger and English, August: An Indian Story. https://openaccess.leidenuniv.nl > bitstream > handle, 22nd Nov. 2021 Sefa, George. Rethinking the Role of Indigenous Knowledges in the Academy NALL Working Paper, 2002. http://www.oise.utoronto.ca/depts/sese/csew/nall/res/58GeorgeDei.pdf. 15th Nov. 2021 Venkateswarlu, Yesapogu. The Impact of Post Colonialism in Amitav Ghosh's Novels-A Post Colonial Perspective, 2013. https:// www.arcjournals.org > pdfs > ijsell 15th Nov. 2021

Isuru Ayeshmantha Rathnayake works in the capacity of a Lecturer in the Department of English, the University of Kelaniya, Sri Lanka from where he also holds a BA (Honours) in English Studies. Being a visually challenged person himself, his research examines the intersections of disability studies, critical pedagogy and South Asian Literature. 